\title{
PENGARUH BEBAN, MOTIVASI DAN KEPUASAN KERJA TERHADAP KINERJA PEGAWAI PELAYANAN PAJAK PRATAMA CILEUNGSI
}

\author{
Oleh: \\ Aris Hidayat Kurniawan'), Sri Lestari Prasilowati2) \\ Sekolah Tinggi Ilmu Ekonomi IPWI Jakarta \\ Email: masarda265@gmail.com
}

\begin{abstract}
Oversight Office of Cileungsi First th Tax Service seeks to improve the best service to commerce and community, through profesional service with quality work and better performance. There is still not optimal employee performance, it is thought the fact that there to be caused by a perceived high workload resulting in lower job motivation and job satisfaction of employees. Research conducted at Office of Cileungsi First'th Tax Service by taking 89 employees as the research sample. Data were collected by quitionnaire instruments covered by five rating scale from strongly disagree to strongly agree. Quantitative research was conducted by discribing and verification data. The Multiple linear regression analysis are the statistic approach to data analysis. Hypothesis testing are done by t-test and F-test. The study produced three major finding consistent with the hypothesis put forward, that are: 1) the workload of employees are in the high category, 2) work motivation is in the high category, 3) job satisfaction is in the high category and the performance is in the category of not bad. Base on research finding, in order to increase employee performance can be done by manage the workload of employees, increase work motivation and increase job satisfication.
\end{abstract}

Kata kunci:

Workload, Job Motivation, Job Satisfaction and Performance

\section{PENDAHULUAN}

Dewasa ini setiap institusi atau organisasi berusaha memperoleh sumber daya manusia yang sesuai dengan kebutuhan. Selain sumber daya manusia yang sesuai Institusi atau Organisasi juga memerlukan sumber daya lain misalnya program atau kebijakan, keorganisasian, sarana dan prasarana. Namun pada kenyataannya dapat dipastikan bahwa sebuah organisasi akan sulit dan bahkan cenderung gagal dalam mencapai tujuannya, jika mengabaikan sumber daya manusia. Dengan mewujudkan sumber daya manusia organisasi akan mampu mencapai tujuan bisnis dan berbagai keuntungan Iainnya. Globalisasi di era pasar bebas ini membuat seluruh elemen harus mampu bersaing dengan para pesaingnya baik lokal maupun 
internasional, termasuk didalamnya persaingan sumber daya manusia itu sendiri. Kecanggihan teknologi yang dulu menjadi ciri kemajuan zaman modern kini tidak lagi menjadi nomor wahid yang begitu diagungkan, namun kebutuhan manusia yang mampu menguasai teknologi dan budaya produksi lebih mendominasi dalam era persaingan global, sehingga peran manusia produktif amat diperlukan dalam menjamin keunggulannya, karenanya diperlukan keselarasan antara strategi pengembangan secara umum dan perencanaan sumber daya manusia yang tepat. Dengan kata lain sumber daya yang ada merupakan satu kesatuan, yang satu sama lain tidak dapat dipisahkan dan saling menunjang karena sumber daya manusia merupakan tenaga pengelola yang bertanggung jawab untuk memanfaatkan sumber daya lainnya didalam suatu organisasi. Sumber daya manusia atau lebih dikenal dengan istilah pegawai merupakan inti dalam suatu institusi, karena semua unsur tidak akan berfungsi tanpa ditangani

oleh pegawainya. Manajemen yang efektif adalah kunci bagi keberhasilan organisasi tersebut, keberhasilan sangat mungkin dicapai manakala peraturan atau kebijakan dan prosedur, serta mekanisme kerja yang berhubungan dengan manusia dan organisasi tersebut saling berhubungan dan memberikan sumbangan terhadap pencapaian tujuan perusahaan serta pencapaian strategis. Oleh karena itu perlu adanya pengelolaan sumber daya manusia karena manajemen sumber daya manusia yang efektif merupakan kunci keberhasilan suatu organisasi. Selain itu sumber daya manusia merupakan satu-satunya sumber daya yang memiliki rasio, rasa dan karsa, dimana semua potensi sumber daya manusia tersebut berpengaruh terhadap upaya organisasi dalam mencapai tujuan.
Betapapun majunya teknologi, perkembangan informasi, tersedianya modal dan memadainya bahan, jika tanpa sumber daya manusia sulit bagi oganisasi untuk mencapai tujuannya. Untuk menghadapi perubahan yang makin pesat dan beraneka ragam, organisasi dituntut agar dapat mengembangkan kemampuan manajemen guna mengantisipasi kejadian serta perubahan yang mungkin terjadi dalam kurun waktu yang singkat maupun jangka waktu yang panjang, untuk itu manajemen dituntut untuk mampu menentukan strategi yang handal, salah satunya menentukan strategi perusahaan yang berorientasi pada pengembangan sumber daya manusia. Manajemen yang baik adalah manajemen yang dapat menciptakan dan mengembangkan motivasi kerja yang berbasis pada pegawai yang memiliki integritas tinggi dan didukung oleh sistem remunerasi yang baik, transparan dan berbasis pada kebutuhan ekonomi pegawai saat ini. Manajemen yang baik adalah manajemen yang mau melakukan perbaikan/mereform dirinya, baik dari sisi internal organisasi/perusahaan seperti merubah paradigma pegawai menjadi agen yang melayani customer, maupun melakukan perubahan untuk pihak luar, seperti menciptakan pencitraan organisasi dimata masyarakat. Salah satu produk perubahan manajemen intansi pemerintah adalah mereform paradigma dibidang ekonomi, yaitu menciptakan kesadaran akan pentingnya kemandirian pembiayaan pembangunan nasional dimana pada rezim Soeharto hampir semua kegiatan pembangunan dibiayai oleh hutang luar negeri sehingga menyebabkan terjadinya keterpurukan ekonomi-sosial, namun sejak reformasi bergulir paradigma tersebut secara drastis berubah menjadi pembiayaan pembangunan berasal dari sumber daya dari dalam negeri antara lain 
dari pajak. Pajak ini begitu penting karena sumber pendapatan lain yang dulunya diandalkan seperti mineral, minyak bumi dan gas alam serta hasil hutan kini tidak dapat dipertahankan lagi, menyadari hal tersebut pemerintah bertekad untuk menjadikan pajak sebagai tulang punggung penerimaan negara dalam membiayai pembangunan nasional. Namun demikian tidak dapat dipungkiri bahwa image masyarakat terhadap pajak selama ini sebagai suatu hal yang ditakuti. Masyarakat masih memberikan penilaian negatif terhadap pajak baik dari sisi pelayanan yang buruk maupun praktekpraktek korupsi yang terjadi di instansi Direktorat Jenderal Pajak (DJP). Hal tersebut cukup beralasan mengingat media massa pernah memberitakan hasil Survey Transparancy International Indonesia tahun 2005 (Transparansi Internasional Indonesia: 2005:1) terhadap 900 pengusaha di 15 kota di luar Jabotabek menyebutkan bahwa " $40 \%$ sampai dengan $60 \%$ penerimaan pajak dikorupsi oleh aparat pajak", sehingga hal ini perlu dilakukan reformasi dari sisi integritas pegawai pajak.

Korupsi, Kolusi dan Nepotisme telah membudaya di Indonesia juga dialami di lingkungan Direktorat Jenderal Pajak, hal ini terjadi antara lain disebabkan Wajib pajak tidak mau melaporkan secara jujur pajak yang harus dibayar sehingga memberi kesempatan bagi petugas pajak untuk bernegosiasi dengan Wajib pajak. Budaya organisasi yang berlaku tidak tepat sehingga menimbulkan penyimpangan tujuan organisasi, selain itu, pengawasan terhadap petugas pajak masih kurang. Hal ini tercermin dari kurangnya tindakan tegas terhadap petugas pajak yang melakukan penyelewengan sehingga tidak menimbulkan efek jera. Melihat kondisi tersebut diatas, para petinggi di Kementerian Keuangan (Kemenkeu) dan
Direktorat Jenderal Pajak (DJP) yang disponsori oleh International Monetery Fund (IMF) pada akhir tahun 2001 merumuskan suatu visi dan misi yang intinya melakukan perubahan yang signifikan dibidang birokrasi perpajakan berupa reformasi pada struktur organisasi, sistem administrasi perpajakan dan peningkatan integritas pegawai termasuk merubah paradigma pegawai agar lebih profesional dengan menerapkan nilai-nilai organisasi yang baik dan membina integritas pegawai, salah satu elemennya adalah memberikan remunerasi yang mencukupi kebutuhan hidup pegawai dan penghargaan seimbang dengan kinerja pegawai sehingga diharapkan dapat menekan perilaku korupsi dan membentuk pegawai yang memiliki integritas dan profesionalisme tinggi. semua perubahan itu masuk dalam paket reformasi perpajakan. Besarnya tuntutan tersebut membuat institusi/lembaga pemerintah khususnya di lingkungan Direktorat Jenderal Pajak harus mampu mengembangkan strategi yang dinamis dan adaptif untuk menjawab tantangan dan perubahan yang terjadi dalam lingkungannya, kebijakan instansi dimasa yang akan datang lebih dipengaruhi oleh perubahan kondisi lingkungan secara umum. Oleh karena itu pengelola pada berbagai tingkatan dituntut untuk mampu menentukan kebijakan yang dapat memahami lingkungan tersebut dan mendukung rencana makro dimasa yang akan datang. Unsur pelayanan disadari menjadi hal yang sangat penting sesuai visi dan misi Direktorat Jenderal Pajak yaitu memberikan pelayanan yang terbaik kepada Wajib pajak khususnya dan masyarakat pada umumnya. Hal ini menuntut jajaran pegawai, baik atasan maupun bawahan pada Kantor Pelayanan Pajak Pratama Cileungsi untuk memberikan pelayanannya secara 
profesional dengan kualitas kerja dan kinerja yang lebih baik. Kenyataan yang terjadi di Kantor Pelayanan Pajak Pratama Cileungsi, kinerja pegawainya masih belum optimal. Indikasi ketidakoptimalan kinerja dengan adanya Complaine dari masyarakat atau pengguna jasa pelayanan (Wajib pajak) pada Kantor Pelayanan Pajak Pratama Cileungsi.

Kinerja pegawai Kantor Pelayanan Pajak Pratama Cileungsi masih rendah, setiap tahun sejak tahun 2013 terdapat complain dari Wajib pajak perihal kinerja pegawai dalam melayani masyarakat. Meskipun terdapat kecenderungan penurunan data complain tiap tahunnya, namun masih saja belum dapat dikatakan kinerja pegawai sudah baik. Kinerja pegawai dikatakan baik jika respon dari pihak eksternal juga baik. Seiring dengan reformasi birokrasi, tolak ukur atas kinerja Kantor Pelayanan Pajak di lingkungan Direktorat Jenderal Pajak bukan lagi berdasarkan prosentase pencapaian penerimaan yang telah ditargetkan, melainkan dilihat dari Indeks Kinerja Utama (IKU) yang mempunyai komposisi $40 \%$ (empat puluh persen) dari target penerimaan ditambah dengan 60\% (enam puluh persen) dari pertumbuhan penerimaan pajak. Sejalan dengan waktu, muncul fenomena yang bertentangan dengan reformasi birokrasi di Kantor Pelayanan Pajak Pratama Cileungsi, yaitu menurunnya prosentase indeks kinerja utama kantor terhadap pencapaian realisasi penerimaan ditambah target yang dibebankan kepada Kantor Pelayanan Pajak Pratama Cileungsi, dimana pada tahun 2013 prosentase indeks kinerja 105,76\%, tahun 2014 prosentase indeks kinerja adalah 110,94\% namun ditahun, 2015 dan 2016 turun menjadi 67,66\% dan $78,89 \%$ dengan suatu tekanan yang timbul dimana seseorang melakukan pekerjaannya. Bagi pegawai yang menghayati pekerjaan sebagai beban kerja sehingga pegawai mengalami ketegangan didalam pekerjaan karena kemampuannya tidak sesuai dengan tuntutan organisasi maka hal ini akan berdampak pada perilaku yang ditampilkan oleh pegawai tersebut yaitu perilaku tidak efektif dalam bekerja, seperti malas, menghindari tugas atau rendahnya motivasi. Motivasi kerja pegawai dikondisikan oleh kemampuan dan upaya dari pegawai itu sendiri, upaya itu untuk memenuhi sesuatu kebutuhan individual. Rendahnya motivasi kerja pegawai terlihat dari beberapa pegawai yang melakukan aktivitas lain saat bekerja, tidak kreatif dan hanya menunggu perintah atasan, kurang kooperatif dalam bekerja, menunda-nunda pekerjaan.

Kepuasan kerja menggambarkan sikap terhadap pekerjaan yang dirasakan pada evaluasi terhadap aspek-aspek yang berbeda bagi pekerjaan. serta perasaan seseorang mengenai berbagai segi tugastugas pekerjaan, tempat keria dan hubungan dengan sesama pekerja (Osborn dalam Suryana Sumantri, 2001: 83). Sikap seseorang terhadap pekerjaannya tersebut menggambarkan pengalamanpengalaman menyenangkan atau tidak menyenangkan dalam pekerjaan dan harapan-harapan mengenai pengalamanpengalaman mendatang. Munculnya ketidakpuasan pegawai sedapat mungkin akan dihindari oleh pegawai itu sendiri secara individual karena akan mempengaruhi pada tujuan organisasi, seperti motivasi yang rendah, tingkat disiplin yang rendah, kemangkiran yang tinggi, dan lain lain. Kepuasan kerja bersifat individual, setiap orang memiliki tingkat kepuasan yang berbeda-beda sesuai dengan sistem nilai yang berlaku pada dirinya. Semakin banyak aspek-aspek dalam pekerjaannya yang sesuai dengan keinginan individu, semakin tinggi tingkat kepuasan yang dirasakan, begitu juga 
sebaliknya bila semakin sedikit aspekaspek dalam pekerjaan yang sesuai dengan keinginan individu maka semakin rendah tingkat kepuasan yang dirasakan.

\section{TUJUAN PENELITIAN}

Untuk menganalisis pengaruh beban kerja, motivasi kerja dan kepuasan kerja terhadap kinerja pegawai

\section{TELAAH LITERATUR DAN PENGEMBANGAN HIPOTESIS \\ Kinerja}

Kinerja dapat dimaknai dalam banyak hal, diantaranya:

1) Perbuatan, pelaksanaan pekerjaan, prestasi kerja, dan pelaksanaan pekerjaan yang berdaya guna.

2) Pencapaian prestasi seseorang berkenaan dengan tugas yang diberikan kepadanya.

3) Hasil kerja seorang pekerja, sebuah proses manajemen atau suatu organisasi secara keseluruhan, dimana hasil kerja tersebut harus dapat ditunjukkan buktinya secara konkrit dan dapat diukur (dibandingkan dengan standar yang telah ditentukan).

4) Merupakan keberhasilan yang dicapai dalam menyelesaikan suatu pekerjaan atau aktivitas selama periode waktu tertentu (Bernardine dan Russel dalam Sedarmayati, 2007: 260).

Keith Davis (dalam Mangkunegara, 2009: 67) menyebutkan bahwa pencapaian kinerja dipengaruhi oleh faktor kemampuan (ability) dan faktor motivasi (motivation) yang dirumuskan sebagai benkut Human Performance: Ability $X$ Motivation Motivation: Attitude $X$ Situation Ability: Knowledge $X$ Skill Sedangkan menurut Blumberg \& Pringle (dalam Robbins, 2001: 233) selain faktor kemampuan (ability) dan motivasi (motivation), kita perlu menambahkan faktor kesempatan (opportunity to perform) sebagai dimensi dari kinerja, jadi performance $=\mathrm{f}(\mathrm{A} \times \mathrm{M} \mathrm{O}) \mathrm{Hal}$ ini didasarkan pada pemikiran bahwa

walaupun individu mau dan mampu melakukan suatu pekejaan, namun kemungkinan akan menghadapi rintangan yang dapat menghambat kinerja mereka. Pengukuran atau penilaian kinerja penting peranannya sebagai alat manajemen untuk:

1. Memastikan pemahaman pelaksana akan ukuran yang digunakan untuk mencapai kinerja.

2. Memastikan tercapainya rencana kinerja yang disepakati.

3. Memantau dan mengevaluasi pelaksanaan kinerja dan membandingkannya dengan rencana kinerja serta melakukan tindakan untuk memperbaiki kinerja.

4. Memberi penghargaan dan hukuman yang objektif atau kinerja pelaksana yang telah diukur sesuai dengan sistem pengukuran kinerja yang telah disepakati.

5. Menjadi alat komunikasi antar karyawan dan pimpinan dalam upaya memperbaiki kinerja organisasi.

6. Mengidentifikasi apakah kepuasan sudah terpenuhi.

7. Membantu memahami proses kegiatan organisasi.

8. Memastikan bahwa pengambilan keputusan dilakukan secara obyektif.

9. Menunjukkan peningkatan yang perlu dilakukan.

10. Mengungkap permasalahan yang terjadi.

Bernardin \& Russel (dalam Sedarmayati, 2007:261), mengemukakan bahwa "Penilaian kinerja dapat berorientasi pada orang atau individu yaitu fokus pada orang yang dapat menunjukkan perilaku atau berorientasi 
pada pekerjaan, dan fokus pada hasil yang dicapai individu pada pekerjaan."

\section{Beban Kerja}

Beban kerja sering ditafsirkan sebagai suatu hal yang memberatkan atau menekan bagi kehidupan seseorang. Pengertian beban kerja menurut Kamus Besar Bahasa Indonesia adalah kemampuan (kesanggupan, kecakapan) yang dimiliki untuk menyelesaikan masalah, sehingga dengan kemampuan yang dimiliki akan dapat berfungsi dan berproduksi secara proporsional sesuai dengan tugas dan fungsi yang dimiliki. Gibson dan lvancevich (dalam Triya Andina 2010: 18), menjelaskan Tekanan sebagai tanggapan yang dapat menyesuaikan diri, yang dipengaruhi oleh perbedaan individual dan atau proses psikologis, yaitu suatu konsekuensi dari setiap tindakan ekstern (lingkungan, situasi, peristiwa yang terlalu banyak mengadakan tuntutan psikologis dan fisik terhadap seseorang.

Menurut Sugiyanto (dalam Andina, 2010: 18) beban kerja mengandung konsep "penggunaan energi pokok den energi cadangan yang tersedia".

\section{Motivasi Kerja}

Abraham Sperling (dalam Anwar Prabuningrat, 2009: 93) mendefinisikan motif sebagai "suatu kecenderungan untuk beraktivitas, dimulai dari dorongan dalam diri (drive) dan diakhiri dengan penyesuaian diri". Penyesuaian diri ini dikatakan untuk memuaskan motif. Streers den Porter secara umum motivasi merupakan suatu proses yang melibatkan tiga komponen utama yaitu:

1. Pemberi daya pada perilaku manusia (Energizing) Menunjukkan kekuatankekuatan yang ada dalam diri individu untuk mendorong individu tersebut bertingkah laku dengan cara- cara tertentu. Konsep in bertitik tolak dari kekuatan energi individu atau dari kekuatan lingkungan yang sering menggerakkan dorongan tersebut.

2. Pemberi arah pada perilaku manusia (Directing) Konsep ini bertitik tolak dan kekuatan energi individu. Hal ini menunjukkan bahwa tingkah laku individu diarahkan pada suatu tujuan (goal oriented)

3. Bagaimana perilaku itu dipertahankan (Sustaining) Konsep ini bertitik tolak dari suatu sistem yang terdiri dari daya yang terdapat dalam diri individu dan yang terdapat pada lingkungan sekitarnya.

Daya ini memberikan umpan balik pada individu untuk memperkuat intensitas dorongan dan arah energinya atau meminta agar melakukan tindakan tertentu dan mengalihkan usahanya (dalam Sutarto, 2010: 23)

\section{Kepuasan Kerja}

Kepuasan kerja adalah kepuasan karyawan dalam bekerja. Kepuasan kerja sulit didefinisikan karena rasa puas itu bukan keadaan yang tetap karena dapat dipengaruhi dan diubah oleh kekuatarnkekuatan baik dari dalam maupun dari luar lingkungan kerja. Robbins (dalam Wibowo, 2017: 415) mengemukakan bahwa "Kepuasan kerja adalah sikap umum terhadap pekerjaan seseorang yang menunjukan perbedaan antara jumlah penghargaan yang diterima pekerja dan jumlah yang mereka yakini seharusnya mereka terima" Greenberg dan Baron (dalam Wibowo, 2017: 415) “Kepuasan kerja sebagai sikap positif atau negatif yang dilakukan individual terhadap pekerjaan mereka." Kepuasan kerja bersifat individual, setiap orang memiliki tingkat kepuasan yang berbeda-beda sesuai dengan sistem nilai yang berlaku pada dirinya. Semakin 
banyak aspek-aspek dalam pekerjaannya yang sesuai dengan keinginan individu, semakin tinggi tingkat kepuasan yang dirasakan, begitu juga sebaliknya bila semakin sedikit aspek-aspek dalam pekerjaan yang sesuai dengan keinginan individu maka semakin rendah tingkat kepuasan yang dirasakan. Secara umum terdapat 3 (tiga) teori kepuasan kerja yang sudah dikenal yaitu discrepancy theory, equity theory dan two factor theory.

\section{Discrepancy Theory}

Locke (dalam Suryana Sumantrl, 2011: 86), menerangkan bahwa "kepuasan kerja seseorang bergantung pada desrepancy antara (expectation, needs, or values) dengan apa yang menurut perasaannya atau persepsinya telah diperoleh atau dicapai melalui pekerjaan". Dengan demikian, orang akan merasa puas bila tidak ada perbedaan antara yang diinginkan dengan persepsinya atas kenyataan, karena batas minimum yang diinginkan telah terpenuhi.

\section{Equity Theory}

Dikembangkan oleh Adam (dalam Suryana Sumantri 2011: 86) Adapun pendahulu dari teori ini adalah Zaleznik (Suryana Sumantri, 2011: 86). Prinsip teori ini adalah bahwa seseorang akan merasa puas atau tidak puas tergantung apakah ia merasakan adanya keadilan (equity) atau tidak (inequity) atas situasi tertentu. Perasaan equity dan inequity atas situasi diperoleh individu dengan cara membandingkan dirinya dengan orang lain yang sekelas, sekantor maupun di tempat lain.

\section{Two Factor Theory}

Dikembangkan dan dikemukakan oleh Frederick Herzberg (Wexley and Yuki dalam Nur Afrirahmiati, 2012:100). Teori Herzberg ini sebagian besar didasarkan pada rumusan hirarki kebutuhan (Hierarchy of need) dan Maslow. Tingkah Iaku manusia didasari oleh dua macam kebutuhan yang berbeda satu sama lain yaitu kebutuhan fisiologis dan kebutuhan psikologis

\section{Kerangka Penelitian}

Gambar 1

Kerangka Penelitian

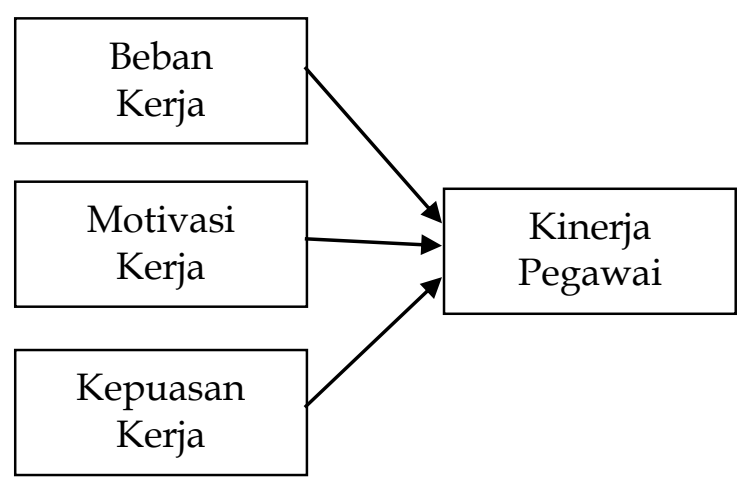

\section{METODE PENELITIAN Sampel Penelitian}

Populasi dan sampel dalam penelitian ini adalah seluruh pegawai Kantor Pelayanan Pajak Pratama Cileungsi

\section{Sumber Data}

Penelitian ini menggunakan data primer. Data data yang diperoleh dalam penelitian ini menggunakan metode Survey, Metode penelitian survey adalah usaha pengamatan untuk mendapatkan keterangan-keterangan yang jelas terhadap suatu masalah tertentu dalam suatu penelitian" (Riduwan. 2008: 275)

\section{Desain Penelitian}

Jenis penelitian yang digunakan adalah penelitian deskriptif dan verifikatif. Penelitian deskriptif merupakan penelitian yang bertujuan untuk memperoleh deskripsi tentang ciri-ciri variabel penelitian. Dalam penelitian ini data dan 
informasi dikumpulkan dari responden dengan menggunakan kuesioner. Setelah data diperoleh kemudian hasilnya akan dipaparkan secara deskriptif dan pada akhir penelitian akan dianalisis untuk menguji hipotesis yang diajukan pada awal penelitian ini (Effendi dalam Riduwan. 2008: 275). Variabel dalam penelitian ini terdiri dari variabel bebas (independent variabel) dan variabel terikat (dependent variabel) Sedangkan penelitian verifikatif pada dasarnya ingin menguji kebenaran dari suatu hipotesis yang dilaksanakan melalui pengumpulan data di lapangan (Suharsimi Arikunto, 2003: 243) Sedangkan desain penelitian merupakan semua proses yang diperlukan dalam perencanaan dan pelaksanaan penelitian. Proses perencanaan dimulai dari identifikasi, pemilihan serta rumusan masalah sampai dengan perumusan hipotesis serta kaitannya dengan teori dan kepustakaan yang ada dan proses selebihnya merupakan tahap operasional dari penelitian. Sedangkan desain penelitian merupakan semua proses yang diperlukan dalam perencanaan dan pelaksanaan penelitian. Proses perencanaan dimulai dari identifikasi, pemilihan serta rumusan masalah sampai dengan perumusan hipotesis serta kaitannya dengan teori dan kepustakaan yang ada dan proses selebihnya merupakan tahap operasional dari penelitian.

\section{Pengumpulan Data}

Jenis data yang dikumpulkan dalam penelitian ini adalah data primer dan sekunder. Teknik pengumpulan data yang digunakan dalam penelitian ini sesuai dengan pendapat Uma Sekaran (2006: 178), yaitu:

1. Observasi, dilakukan untuk mendapatkan data-data tambahan yang melengkapi data kuesioner;
2. Wawancara, mewawancarai langsung kepada pihak perusahaan/organisasi dengan mengajukan pertanyaan yang disiapkan terlebih dahulu kemudian mencatat jawabannya untuk diolah menjadi informasi yang diperlukan:

3. Angket/kuesioner, yaitu mengumpulkan data melalui penyebaran daftar pertanyaan yang bersifat tertutup.

\section{Metode Analisis}

Analisis yang digunakan dalam penelitian ini adalah regresi linier berganda (multiple regression analysis) Regresi linier berganda (multiple regression analysis) adalah satu teknik statistik yang dapat digunakan untuk menganalisa hubungan antara satu variabel dependen tunggal dan beberapa variabel independen (Suyono, 2018:99). Rumus regresi linier berganda adalah sebagai berikut: $\mathrm{Y}=\mathrm{b} 0+\mathrm{b} 1 \mathrm{X} 1+\mathrm{b} 2 \mathrm{X} 2+$ b3X3.

$$
\begin{aligned}
& \mathrm{Y}=\text { Variabel Independen Kinerja } \\
& \mathrm{b}=\text { Konstanta } \\
& \mathrm{b} 1=\text { Koefisien regresi beban kerja } \\
& \mathrm{b} 2=\text { Koefisien regresi motivasi kerja } \\
& \text { b3 }=\text { Koefisien regresi kepuasan kerja } \\
& \mathrm{X} 1=\text { Variabel beban kerja } \\
& \mathrm{X} 2=\text { Variabel motivasi kerja } \\
& \mathrm{X} 3=\text { Variabel kepuasan kerja }
\end{aligned}
$$

\section{HASIL PENELITIAN DAN PEMBAHASAN \\ Hasil Penelitian}

Pengujian normalitas dan asumsi klasik mendapatkan data berdistribusi normal dan terbebas dari persoalan Multikolonielritas, Heteroskedesitas dan autokorelasi sehingga analisis regresi lineasr berganda dapat dilakukan dengan menempatkan beban kerja, motivasi kerja 
dan kepuasan kerja sebagai variabel bebas serta Kinerja sebagai variabel terikat.

Tabel 1

Summary

\begin{tabular}{|l|c|c|}
\hline Model & R & R Square \\
\hline 1 & 0,842 & 0,710 \\
\hline
\end{tabular}

Sumber: Data penelitian diolah, 2018

Nilai korelasi sebesar 0,842 menunjukkan terdapat hubungan yang kuat antara beban kerja, motivasi kerja, dan kepuasan kerja dengan kinerja pegawai. Sedangkan nilai koefisien determinasi sebesar 0,710 menjelaskan kemampuan variasi variabel bebas yang digunakan pada penelitian ini, yakni beban kerja, motivasi kerja, dan kepuasan kerja mampu menjelaskan kinerja pegawai sebesar 71,0\% sedangkan sisanya, 29,0\% dijelaskan oleh variabel bebas lain yang tidak terdapat dalam model penelitian.

Tabel 2

Anova

\begin{tabular}{|rl|r|c|c|}
\hline \multicolumn{2}{|l|}{ Model } & df & F & Sig. \\
\hline 1 & Regression & 3 & 69.215 & $.000^{\mathrm{b}}$ \\
& Residual & 85 & & \\
\multicolumn{2}{|r|}{ Total } & 88 & & \\
\hline
\end{tabular}

Sumber: Data penelitian diolah, 2018

Nilai F sebesar 69,215 dengan tingkat signifikan sebesar 0,000 lebih kecil dari 0,05 sehingga beban kerja, motivasi kerja, dan kepuasan kerja berpengaruh signifikan.

Tabel 3

Koefisien

\begin{tabular}{|c|c|}
\hline Variabel Bebas & Koefisien Regresi \\
\hline Constant & 0,934 \\
\hline Beban Kerja & $-0,132$ \\
\hline Motivasi Kerja & 0,204 \\
\hline Kepuasan Kerja & 0,656 \\
\hline
\end{tabular}

Dependent: Kinerja

Sumber: Data penelitian diolah, 2018
Persamaan model regresi yang digunakan dalam penelitian ini sebagai berikut: $Y=0,934-0,132 X 1+0,204 X 2+$ 0,656X3.

1. Variabel beban kerja negatif sebesar 2,189 dengan nilai p-value sebesar 0,031 atau memiliki nilai kurang dari 0,05 sehingga pengaruhnya signifikan. Arah pengaruh beban kerja adalah negative sebesar -0,132 artinya makin tinggi beban kerja maka kinerja akan menurun.

2. Variabel motivasi kerja positif sebesar 2,584 dengan nilai $p$-value sebesar 0,011 atau memiliki nilai kurang dari 0,05 sehingga pengaruhnya signifikan. Arah pengaruh motivasi kerja adalah positif sebesar 0,204 artinya makin tinggi motivasi kerja maka kinerja akan meningkat.

3. Variabel kepuasan kerja positif sebesar 8,549 dengan nilai p-value sebesar 0,000 atau memiliki nilai kurang dari 0,05 sehingga pengaruhnya signifikan. Arah pengaruh kepuasan kerja adalah positif sebesar 0,656 artinya makin tinggi kepuasan kerja maka kinerja akan meningkat.

\section{Pembahasan}

Beban kerja, motivasi kerja, dan kepuasan kerja berpengaruh signifikan terhadap kinerja pegawai Kantor Pelayanan Pajak Pratama Cileungsi. Nilai korelasi sebesar 0,842 menunjukkan terdapat hubungan yang kuat antara beban kerja, motivasi kerja, dan kepuasan kerja dengan kinerja pegawai. Sedangkan nilai koefisien determinasi sebesar 0,710 menjelaskan kemampuan variasi variabel bebas yang digunakan pada penelitian ini, yakni beban kerja, motivasi kerja, dan kepuasan kerja mampu menjelaskan kinerja pegawai sebesar $71,0 \%$. 


\section{Pengaruh Beban Kerja Terhadap Kinerja Pegawai}

Variabel beban kerja berpengaruh negatif signifikan terhadap kinerja pegawai Kantor Pelayanan Pajak Pratama Cileungsi. Pengaruh yang terjadi bersifat negatif memiliki arti semakin tinggi beban kerja yang dirasakan oleh pegawai Kantor Pelayanan Pajak Pratama Cileungsi maka akan semakin rendah kinerja pegawai. Sebaliknya semakin rendah beban kerja yang dirasakan oleh pegawai Kantor Pelayanan Pajak Pratama Cileungsi maka akan semakin tinggi kinerja.

Beban kerja yang dirasakan sebagian besar pegawai Kantor Pelayanan Pajak Pratama Cileungsi termasuk tinggi. Fasilitas fisik yang disediakan Kantor Pelayanan Pajak Pratama Cileungsi cukup memadai menurut sebagian besar pegawai untuk mendukung pelaksanaan pekerjaan dan faktor psikis yang dirasakan pegawai Kantor Pelayanan Pajak Pratama Cileungsi sudah mendukung dalam pelaksanaan pekerjaan.

\section{Pengaruh Motivasi Kerja Terhadap Kinerja Pegawai}

Variabel motivasi kerja berpengaruh positif signifikan terhadap kinerja pegawai Kantor Pelayanan Pajak Pratama Cileungsi. Pengaruh yang terjadi bersifat positif memiliki arti semakin tinggi motivasi kerja pegawai Kantor Pelayanan Pajak Pratama Cileungsi maka akan semakin tinggi kinerja pegawai. Sebaliknya semakin rendah motivasi kerja pegawai Kantor Pelayanan Pajak Pratama Cileungsi maka akan semakin rendah kinerja pegawai tersebut. Hasil penelitian ini sesuai dengan penelitian sebelumnya yang dilakukan oleh Sjam (2012) dan Budiman (2011) yang menunjukkan terdapat pengaruh motivasi kerja terhadap kinerja pegawai.
Motivasi kerja sebagian besar pegawai Kantor Pelayanan Pajak Pratama Cileungsi sudah tinggi. Pada umumnya pegawai di Kantor Pelayanan Pajak Pratama Cileungsi sudah memiliki motif berprestasi dan motif bersahabat yang tinggi.

\section{Pengaruh Kepuasan Kerja Terhadap Kinerja Pegawai}

Variabel kepuasan kerja berpengaruh positif signifikan terhadap kinerja pegawai Kantor Pelayanan Pajak Pratama Cileungsi. Pengaruh yang terjadi bersifat positif memiliki arti semakin tinggi kepuasan kerja pegawai Kantor Pelayanan Pajak Pratama Cileungsi maka akan semakin tinggi kinerja pegawai. Sebaliknya semakin rendah kepuasan kerja pegawai Kantor Pelayanan Pajak Pratama Cileungsi maka akan semakin rendah kinerja pegawai tersebut. Sebagaimana yang dikatakan oleh Wijono (2010: 118) bahwa kepuasan kerja merupakan salah satu faktor yang penting untuk dapat meningkatkan kinerja karyawan dan adanya ketidakpuasan pada pegawai menyebabkan prestasi dan kinerja pegawai menurun.

Kepuasan kerja sebagian besar pegawai Kantor Pelayanan Pajak Pratama Cileungsi cukup tinggi. Sebagian besar pegawai di Kantor Pelayanan Pajak Pratama Cileungsi cukup puas atas imbalan yang diterima dan juga puas atas pengawasan yang diberikan.

\section{KESIMPULAN}

1. Beban kerja berpengaruh terhadap kinerja pegawai Kantor Pelayanan Pajak Pratama Cileungsi dengan arah negative sebesar - 2,189; makin tinggi beban kerja makin rendah kinerja pegawai.

2. Motivasi kerja berpengaruh terhadap kinerja pegawai Kantor Pelayanan 
Pajak Pratama Cileungsi dengan arah positif sebesar 0,204; makin tinggi motivasi kerja makin tinggi kinerja pegawai

3. Kepuasan kerja berpengaruh terhadap kinerja pegawai Kantor Pelayanan Pajak Pratama Cileungsi dengan arah positif sebesar 0,656; makin tinggi kepuasan kerja makin tinggi kinerja pegawai.

\section{SARAN}

1. Pemberian beban kerja yang sesuai dengan standar kerja seperti kuantitas pekerjaan yang disesuaikan dengan kapasitas waktu tersedia dan Kepala Kantor sebagai Pimpinan tertinggi Kantor Pelayanan Pajak Pratama Cileungsi perlu menambah sarana dan prasarana untuk pegawai seperti menambah pendingin udara, melakukan pembaruan komputer pegawai dan fasiltas ruang kerja pegawai, selain itu dengan pemberian intensif kepada karyawan sehingga beban kerja yang yang dihadapi karyawan dirasa sepadan dengan apa yang didapat, dan juga dipandang perlu bagi institusi dalam hal ini Direktorat Jenderal Pajak hendaknya meninjau kembali ketersediaan pegawai yang jumlahnya tidak memadai dibandingkan dengan jumlah pekerjaan yang harus diselesaikan, yaitu dengan merekrut pegawai baru sesuai dengan kebutuhan.

2. Memberikan kesempatan luas dan adil kepada para pegawai Kantor Pelayanan Pajak Pratama Cileungsi untuk memenuhi berbagai kebutuhan, seperti kebutuhan berprestasi atau mewujudkan keberhasilan, pengakuan, tanggung jawab dan pengembangan diri pegawai sesuai dengan kemampuan dan kompetensi yang dimiliki.

3. Memberikan upah yang adil dan sesuai dengan tugas dan tanggungjawab yang diberikan organisasi, tunjangan yang memadai, memberikan kesempatan promosi untuk jenjang karir yang lebih baik, dan pemberian supervisi yang baik.

\section{DAFTAR PUSTAKA}

A.A Anwar Prabu Mangkunegara, 2009. Manajemen Sumber Daya Manusia Perusahaan, Bandung : Penerbit PT. Remaja Rosdakarya.

Davis, Keith, 1982. Human Behavior At Work Organizational Behavior Sixth Edition. Tata McGraw-Hill Company Ltd New Delhi

Herzberg, F, 1959. The Motivation To Work. Second Edition. New York. J. Wiley \& Son. S Inc

Kenneth N, Yuki, Gary A. 1997: Organization Behavior, Fourth Edition, New York, McGraw-Hill Book Company

Masri Singarimbun dan Sofian Effendi, 2005. Metode Penelitian Survei. Jakarta: Pustaka LP3ES

Newstorm, John W. \& Davis, Keith 1993 Human Behavior at Work 9th Edition: USA: MCGraw-Hill Inc

Riduwan, 2008. Metode dan Teknik Menyusun Tesis. Bandung : ALFABETA

Robbins. P. Stephen. 2001. Prinsip Prinsip Perilaku Organisasi. Edisi Keempat, Jakarta: Penerbit Erlangga

Sekaran, Uma, 2006. Metodologi Penelitian Untuk Bisnis Edisi 4 Buku 1. Jakarta: Salemba Empat

Suharsimi Arikunto. 2006. Prosedur Penelitian, Suatu Pendekatan Praktek Edisi Revisi VI. Jakarta : Penerbit Rineka Cipta

Suryana Sumantri. 2001 . Perilaku Organisasi. Bandung : Universitas Padjajaran

Suyono. 2018. Analisis Regresi Untuk Penelitian. Yogyakarta: Deepublish. 
Triya Andina. 2007. Hubungan Antara Beban Kerja Dengan Hasil Kerja Pada Karyawan Oprator Bagian Weaving Divisi Produksi Di CV. Kencana Hegar
Bandung. Bandung : Universitas Islam Bandung

Wijono, Sutarto. 2010. Psikologi Industri dan Organisasi. Jakarta : Prenada Media Group 